\title{
Medievalista
}

\section{O Luto em Portugal: da Corte à Gente Comum (séculos XV-XVI)}

Mourning in Portugal: from the Court to the Common People (15th-16th centuries)

\section{Ana Mafalda Pereira Lopes}

\section{OpenEdition}

\section{Journals}

\section{Edição electrónica}

URL: http://journals.openedition.org/medievalista/1360

DOI: $10.4000 /$ medievalista. 1360

ISSN: $1646-740 X$

\section{Editora}

Instituto de Estudos Medievais - FCSH-UNL

\section{Refêrencia eletrónica}

Ana Mafalda Pereira Lopes, " O Luto em Portugal: da Corte à Gente Comum (séculos XV-XVI) », Medievalista [Online], 22 | 2017, posto online no dia 01 dezembro 2017, consultado no dia 20 abril 2019. URL : http://journals.openedition.org/medievalista/1360 ; DOI : 10.4000/medievalista. 1360

(C) IEM 
Título / Title: O Luto em Portugal: da Corte à Gente Comum (séculos XV-XVI) / Mourning in Portugal: from the Court to the Common People (15th-16th centuries)

Autor(es) / Author(s): Ana Mafalda Pereira Lopes

Universidade / University: Universidade do Minho

Faculdade e Departamento / Unidade de Investigação - Faculty and Department /

Research Center: Instituto de Ciências Sociais

Código Postal / Postcode: 4710-057

Cidade / City: Braga

País / Country: Portugal

Email Institucional / Institutional email: anamafaldaplopes@gmail.com

Fonte: Medievalista [Em linha]. Direc. Bernardo Vasconcelos e Sousa. Lisboa: IEM.

Disponível em:

http://www2.fcsh.unl.pt/iem/medievalista/MEDIEVALISTA22/lopes2207.html

ISSN: 1646-740X

Data recepção do artigo / Received for publication: 25 de Janeiro de 2017

Data aceitação do artigo / Accepted in revised form: 11 de Maio de 2017 


\section{Resumo}

O presente estudo lança um breve olhar sobre os rituais do luto na perspetiva da História das Emoções, campo recente que nos permite abordar as ações e os comportamentos do passado segundo novas perspetivas. Analisámos as manifestações de luto na transição da Idade Média para Época Moderna, tendo presente o contexto histórico e político no qual se inserem. Através de uma análise focada sobretudo nas crónicas régias, verificamos que, pelo menos entre os grupos cortesãos, se registou uma tendência crescente para a privatização da dor, através do progressivo desaparecimento da expressão violenta de emoções, ao passo que estas se mantiveram inalteradas no seio da gente comum.

Palavras-chave: luto; história das emoções; morte; rituais; crises sucessórias.

\section{Abstract}

The following study casts a brief look at the rituals of mourning within the perspective of the History of the Emotions, a recent but relevant historical field that intends to interpret under a new light habits and actions from the past. We will analyze the concepts and practices of mourning and their evolution throughout the Early Modern period, by reviewing the contents mainly of royal chronicles, inserting the narratives of mourning in their political contexts. Our study suggests that, at least among court circles, there was a tendency towards the privatization of pain, through the progressive disappearance of violent expressions of emotion, while the latter remained mostly unaltered among the common people.

Keywords: rites of mourning; history of emotions; death; dynastic crises. 


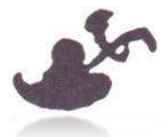

\section{O Luto em Portugal: da Corte à Gente Comum (séculos} XV-XVI) / Mourning in Portugal: from the Court to the Common People (15th-16th centuries)

\author{
Ana Mafalda Pereira Lopes*
}

\section{Introdução: o luto e a História das Emoções}

Embora existam vários trabalhos sobre a história das atitudes perante a morte, o luto não tem sido objeto específico de estudo. Este reveste-se de uma ampla panóplia de manifestações de dor e tristeza e, como tal, está intimamente ligado às emoções e à forma como estas foram mudando ao longo da História.

O campo da História das Emoções é recente e ao mesmo tempo bastante complexo. Valoriza as emoções para lá da visão da psicologia (que as considera de forma isolada, focando-se no indivíduo e nos seus traços específicos), estando mais interessada na complexidade social e cultural das emoções, e em colocá-las numa perspetiva temporal e espacial ${ }^{1}$. As emoções são sentidas imediatamente pelos indivíduos através de alterações corporais ou mentais, e são impulsionadoras de uma ação publicamente observável. No entanto, ao estudar as emoções numa perspetiva histórica, é necessário analisá-las não como atos isolados ou irracionais, mas tendo em conta que são construídas social e individualmente. A História analisa as emoções e as formas como estas se representam tendo em conta o ambiente social e institucional no qual o indivíduo ou os grupos sociais se inserem, acabando estes por se influenciar mutuamente. $\mathrm{O}$ contexto espacial, mas também temporal, influencia o comportamento

\footnotetext{
* Este artigo corresponde a um dos capítulos da nossa dissertação de mestrado, devidamente revisto e ampliado (LOPES, Ana Mafalda - Confortando reis e rainhas: as cartas consolatórias entre a política e o luto (séculos XV-XVI). Braga: Universidade do Minho, 2017. Dissertação de Mestrado).

${ }^{1}$ FREVERT, Ute - Emotions in History: Lost and Found. Budapest: Central European University Press, 2011, p. 24.
} 
dos indivíduos, assim como as ações ligadas às emoções podem interferir nas sociedades de que fazem parte. As experiências pessoais, as memórias e tradições, são igualmente relevantes para explicar comportamentos e ações. Ao analisar as emoções e as reações do indivíduo perante o seu meio social e cultural, perante o outro e perante si, podemos perceber o que uma sociedade considera bom ou mau, justo ou injusto, certo ou errado, e de que forma o homem controla ou não as suas emoções.

O estudo das emoções na História levanta, contudo, bastantes problemas. Em primeiro lugar, o historiador está afastado em termos temporais das emoções do passado, tendo já enraizada uma dada cultura emocional, acabando por observá-las através de filtros culturais do seu próprio tempo e país. Este só pode imaginar as emoções de outras pessoas a partir de expressões externas como palavras, gestos e ações, que oferecem pistas de como elas as experienciaram e lidaram com elas. Ainda assim, olhar para si mesmo como que para um espelho, pode ajudar na forma de entender os outros ${ }^{2}$. Em segundo lugar, os historiadores lidam com ambientes ricos em complexidade institucional e realidades apenas parcialmente reconstituíveis e, como tal, é provável que muitas vezes não encontrem uma evidência causal clara para certas atitudes ou expressões emocionais. Mesmo quando os historiadores tentam testar uma hipótese, comparando casos semelhantes com caraterísticas ligeiramente diferentes, devem-se esforçar para não perder de vista a complexidade do caso observado. Por definição, as emoções são instáveis e variáveis, escapando muitas vezes à atenção do historiador, uma vez que ficam guardadas para sempre no indivíduo, podendo seguir padrões biológicos impossíveis de relacionar com eventos sociais e políticos ${ }^{3}$. Por último, as ideias e os conceitos sobre o que são emoções mudaram ao longo do tempo, e dependem dos diferentes contextos culturais ou diferem dentro de uma mesma cultura ${ }^{4}$.

\footnotetext{
2 IKEGAMI, Eiko - "Emotions". in RUBLACK, Ulinka (ed.) - A concise companion to history. Oxford: Oxford University Press, 2012, p. 337.

${ }^{3}$ FREVERT, Ute - Emotions in History..., p. 26.

${ }^{4}$ A palavra emoção, tal como se entende hoje em dia, é recente. Na Época Moderna, as emoções eram tidas como afetos ou paixões, sentimentos que alteravam momentaneamente o estado de espírito do indivíduo, rompendo com sua a serenidade, quietude e tranquilidade da alma, e impulsionavam determinadas ações como a ira, vingança, tristeza ou alegria (TAUSIET, María; AMELANG, James (ed.) - Accidentes del Alma: Las Emociones en la Edad Moderna. Madrid: Abada Editores, 2009, p. 8).
} 
Apesar destas dificuldades, o facto é que as emoções são importantes para a compreensão da História na medida em que as ações humanas movidas por estados emocionais podem resultar em importantes consequências para a vida pessoal ou social do indivíduo, bem como para a própria sociedade em que ele se insere. As pessoas no passado conheciam, tal como agora, a importância e o perigo das emoções. Além disso, o seu estudo e análise permite-nos identificar continuidades ou ruturas comportamentais, que variam conforme a época e conforme os contextos culturais nos quais os indivíduos estão inseridos. De facto, segundo María Tausiet e James Amelang, as palavras e gestos que acompanhavam a expressão das emoções davam forma ao sentimento, transformando-o e clarificando-o, permitindo-lhe evoluir. Consequentemente, a "sinceridade" das emoções é colocada em causa, levando alguns autores a pensar se não foram os próprios rituais que construíram determinadas emoções $^{5}$. Assim, desde a Antiguidade até à Época Moderna, é visível uma mudança na forma de lidar com as emoções, percetível através dos comportamentos, gestos e palavras que elas impulsionam. Nobert Elias chamou pela primeira vez a atenção para um processo evolutivo a que chamou de "processo civilizacional", defendendo um crescente autocontrolo no caminho para a modernidade em comparação com a Idade Média, bem como a regulação das interações humanas nas sociedades ocidentais como o ponto de viragem para o autocontrolo emocional ${ }^{6}$.

Neste contexto, sabemos hoje que as próprias manifestações de dor e de luto codificadas socialmente foram objeto de uma evolução entre finais da Idade Média e a Idade Moderna e, tal como as emoções, assistiram a um processo de autocontrolo, passando as suas manifestações de públicas a privadas. Nas sociedades medievais e modernas tomar luto era, ao contrário dos dias de hoje, bastante frequente, fazendo-se luto por mortes, desastres nacionais ou acontecimentos infaustos ocorridos fora do reino. Este manifestava-se nos prantos e lamentações públicas, no corte e no despentear dos cabelos, no arrancar ou no deixar crescer as barbas, no abandono dos preceitos de higiene, no desprezo pelo corpo, na cor das roupas e nos tipos de tecido utilizados ${ }^{7}$.

\footnotetext{
5 TAUSIET María; AMELANG, James - Accidentes del Alma..., p. 17.

${ }^{6}$ Sobre o assunto leia-se ELIAS, Nobert - O processo civilizacional: investigações sociogenéticas $e$ psicogenéticas. Vol. 1 e 2. Lisboa: Publicações Dom Quixote, 1990.

${ }^{7}$ MARQUES, A. H. de Oliveira - A Sociedade Medieval Portuguesa. $3^{\mathrm{a}}$ ed. Lisboa: Livraria Sá da Costa, 1974, pp. 215-216.
} 
No entanto, na transição do século XV para o século XVI, o luto sofreu algumas transformações. Ainda que o período aqui analisado seja curto (1491-1557), este adquiriu novas formas, sobretudo no seio das elites cortesãs e aristocráticas, que foram abandonando as práticas de luto medievais para dar lugar a outros rituais. O luto passou a expressar-se através do vestuário, da duração e da intensidade do luto, e em cerimónias fúnebres mais sofisticadas, mas menos violentas em termos comportamentais. A literatura produzida em contexto fúnebre, sob a forma de panegíricos, epitáfios, sermões fúnebres e cartas consolatórias, também contribuiu para esse processo evolutivo. No entanto, por parte da gente comum, continuava a verificarse a permanência de velhas formas de luto como os prantos e o recurso a carpideiras, que iriam permanecer na cultura popular até bem entrado o século $\mathrm{XX}^{8}$. O luto passou, assim, de uma manifestação mais ou menos espontânea da dor, para um comportamento ritualizado e controlado, próprio de um "processo civilizacional" que entra em curso no final da Idade Média e que continua no caminho para a Modernidade.

Este artigo aborda manifestações de luto e de dor da família real (principalmente na morte de monarcas e príncipes herdeiros, pelo seu enorme impacto junto das comunidades) e da gente comum, tendo em conta os comportamentos e os afetos demonstrados. Estes comportamentos estão relatados nas crónicas, onde se observa que, à medida que avançamos na cronologia, as descrições dos rituais vão ganhando mais relevância, enquanto os sentimentos de dor passam a estar expressos nas cartas pessoais e privadas ${ }^{9}$. Por isso, a maioria das informações aqui contidas provêm de crónicas ou de bibliografia sobre o assunto, e analisadas na perspetiva da História das Emoções, observando a forma como estas manifestações de dor evoluíram do público ao privado.

\footnotetext{
8 Sobre o assunto leia-se VASCONCELOS, J. Leite de - Etnografia portuguesa. Vol. X. Lisboa: Imprensa Nacional-Casa da Moeda, 2007, pp. 308-309; BRAGA, Teófilo - O povo português nos seus costumes, crenças e tradições. Vol. I. Lisboa: Publicações Dom Quixote, 1985, pp. 147-179.

${ }^{9}$ É sabido que a maior parte das cartas íntimas desapareceram, e que se encontram poucos exemplares disponíveis. De qualquer forma, não são objeto deste artigo.
} 


\section{O luto do final da Idade Média ao alvorecer da Modernidade (1491-1521)}

\subsection{O fatídico ano de 1491: a morte do príncipe D. Afonso}

O ano de 1491 assistiu a um dos maiores infortúnios que se abateu sobre a família de Avis e que propiciou as mais sentidas e generalizadas demonstrações de luto que alguma vez se haviam registado em Portugal. Único filho de D. João II e D. Leonor, o jovem príncipe herdeiro D. Afonso, de apenas 16 anos, faleceu a 13 de Julho de 1491 sem deixar descendentes, e o Reino sem sucessor ${ }^{10}$. O luto por D. Afonso revelou certas continuidades com as práticas antigas de luto, mas também deixou entrever a imposição de uma nova atitude perante a morte, principalmente por parte da família real, a quem se impunha um comportamento concordante com a sua condição social. Ainda assim, como estamos numa altura de transição e de ajustamento de comportamentos, a família real não deixou de demonstrar publicamente o seu luto, abandonando normas e preceitos em prol da demonstração das suas emoções mais sinceras.

Na Idade Média, as demonstrações de luto revestiam-se de um caráter violento nas quais as pessoas se esbofeteavam, os homens arrancavam os cabelos e as barbas, e as mulheres arranhavam as caras com as suas próprias mãos. Estas manifestações de luto, assim como os prantos e as lamentações, eram praticadas por todos, desde o rei aos seus súbditos. De facto, como recorda Javier Varela, durante o Renascimento o cortesão iguala-se aos mais humildes no luto e nas manifestações espontâneas de dor ${ }^{11}$. Ainda que pareçam consequência de atos irrefletidos, estas manifestações faziam parte de um padrão comportamental ou de um ritual que se devia seguir, acabando por ser praticamente obrigatórias em situações de luto.

As explicações para estes comportamentos violentos podem ser várias. Segundo Georges Duby, infligir a si próprio a dor e deixar esse sofrimento plasmado no seu

\footnotetext{
${ }^{10}$ Sobre a morte do príncipe D. Afonso leia-se SÁ, Isabel dos Guimarães - De princesa a rainha-velha: Leonor de Lencastre. Lisboa: Círculo de Leitores, 2011, pp. 141-150; SÁ, Isabel dos Guimarães Rainhas consortes de D. Manuel I: Isabel de Castela, Maria de Castela e Leonor da Áustria. Lisboa: Círculo de Leitores, 2012, pp. 64-70; e CARVALHO, Elisa Maria Domingues da Costa - "A Morte Régia em Portugal na Idade Média: Aspectos Rituais e Atitudes Perante a Morte". Cadernos do Noroeste 9:2 (1996), pp. 157-248.

${ }^{11}$ VARELA, Javier - La muerte del rey: el ceremonial funerario de la monarquía española (1500-1885). Madrid: Turner, 1990, pp. 30-31.
} 
corpo, poderia ser uma forma das sociedades prolongarem na memória acontecimentos importantes ${ }^{12}$. Javier Varela, por seu turno, defende que esta seria uma forma de causar algum bem ao morto oferecendo-lhe o sacrifício de uma parte valiosa, o sangue ou o cabelo, do corpo dos vivos ${ }^{13}$. Quanto aos prantos e às lamentações, estes eram uma forma ritual de exprimir e afastar o sofrimento, a dor causada pela morte, devendo a sua intensidade aumentar quanto maior fosse a perturbação do enlutado ${ }^{14}$. Próprios de um "luto selvagem", citando as palavras de Philippe Ariès, estes comportamentos tinham uma origem pagã e podiam ser feitos pelos familiares, amigos e vassalos do defunto, mas também por pessoas contratadas, que se denominavam carpideiras ou pranteadeiras.

Enquanto práticas coletivas, os prantos e as lamentações, bem como as cerimónias fúnebres, podem ser vistos como uma forma de socializar e de partilhar um mesmo sentimento de perturbação e insegurança, fomentando laços de solidariedade entre a comunidade que a ajudariam a ultrapassar a perturbação e lhe confeririam estabilidade $^{15}$. Este luto seria uma defesa contra a desordem instalada no seio de uma comunidade, dependente da ação mais ou menos importante que o defunto protagonizou enquanto vivo. María Tausiet e James Amelang também foram ao encontro desta ideia, afirmando que estes "lamentos rituais" pretendiam resolver uma "crise de presença", quer a nível pessoal e psicológico, quer a nível coletivo, conferindo algum tipo de estabilidade ao indivíduo e à comunidade ${ }^{16}$. De acordo com José Mattoso, esta prática, bastante comum na Antiguidade Clássica, chegara até à Idade Média inalterada nos gestos mas claramente ligada aos pressupostos cristãos. Na Antiguidade, as lamentações pretendiam reter o defunto no mundo dos vivos, constituindo um reflexo da impotência por parte dos enlutados de o fazer regressar à vida. Agora, acreditava-se que as lágrimas, a dor e o sofrimento que acompanhavam as lamentações podiam influenciar Deus, servindo para pedir perdão dos pecados pelo defunto. Além disso, quanto mais intensas fossem mais eficácia teriam ${ }^{17}$. A Igreja e o poder civil tentaram, no entanto,

\footnotetext{
12 DUBY, Georges - El amor en la Edad Media y otros ensayos. Madrid: Alianza Editorial, 1990, p. 185.

${ }^{13}$ VARELA, Javier - La muerte del rey..., pp. 30-31.

14 MATTOSO, José - "Pressupostos Mentais do Culto dos Mortos". Arqueologia: Revista do Campo Arqueológico de Mértola 5 (1997), p. 8.

${ }^{15}$ MATTOSO, José - “O Poder e a Morte”. Anuário de Estudos Medievais 25 (1995), p. 398.

16 TAUSIET, María; AMELANG, James - Accidentes del Alma..., p. 216.

${ }^{17}$ MATTOSO, José - O Reino dos Mortos na Idade Média Peninsular. Lisboa: João Sá da Costa, 1996, p. 58; TAUSIET, María; AMELANG, James - Accidentes del Alma..., p. 144.
} 
proibir estas manifestações por considerar que atribuíam pouca importância à vida eterna ${ }^{18}$. Mas o facto é que os prantos e as lamentações ainda se fizeram sentir na morte do príncipe D. Afonso, permanecendo como prática comum ainda no século passado.

A morte do príncipe herdeiro D. Afonso significou um abalo não só na estrutura familiar da monarquia, como também no reino. Nesta época, a morte régia afetava a sobrevivência dinástica e por conseguinte o próprio Reino, existindo uma "comunhão entre o destino individual dos monarcas e seus herdeiros e o destino vital da própria Nação" ${ }^{19}$. A morte do príncipe herdeiro simbolizava o fim da "verdadeira esperança, e paz, sossego, e amparo" de todo o reino, que se via agora sem um sucessor e perante um futuro incerto ${ }^{20}$. O Reino sentia-se como órfão de pai, provocando no povo sentimentos de insegurança, perturbação e receio perante o futuro ${ }^{21}$. Conta-nos Garcia de Resende que, aquando da morte do príncipe D. Afonso, "se levantou entre todos um muito grande, e muito triste, e desaventurado pranto, dando todos em si muitas bofetadas, depenando muitas e muito honradas barbas, e cabelos, e as mulheres desfazendo com as suas unhas, e mãos, a fermosura de seus rostos, que lhe corriam em sangue" 22 . No mês seguinte, no saimento que teve lugar no mosteiro da Batalha, panteão da dinastia de Avis, ouviram-se "grandes, e espantosos prantos, e doridas lamentações do Rei, e do Duque, e de todos do Reino que aí eram, e grandes gritos, e carpidos das senhoras, e honradas mulheres" 23 .

A nível familiar a perda do seu único filho constituiu um forte abalo emocional nos monarcas, que viam o seu filho partir na flor da idade sem deixar descendência. D. Afonso, recém-casado, deixava ainda viúva a jovem princesa D. Isabel. O rei, a rainha e a princesa, apesar de não lhes ser aconselhado este tipo de manifestações, abandonaram

\footnotetext{
${ }^{18}$ MARQUES, A. H. de Oliveira - A Sociedade Medieval..., p. 214; MATTOSO, José - O Reino dos Mortos..., p. 111. Sobre as proibições canónicas dos prantos e lamentações durante a Idade Média leia-se VARELA, Javier - La muerte del rey..., p. 30; BEIRANTE, Maria Ângela - "Para a história da morte em Portugal (séc. XII-XIV)". in Estudos de História de Portugal. Homenagem a A. H. Oliveira Marques. Vol. I: Séc. V-XVI. Lisboa: Estampa, 1982, pp. 378-379.

${ }^{19}$ CARVALHO, Elisa Maria Domingues da Costa - A morte régia..., p. 196.

${ }^{20}$ RESENDE, Garcia de - Crónica de D. João II e Miscelânea. Ed. Joaquim Veríssimo Serrão. Lisboa: Imprensa Nacional-Casa da Moeda, 1991, p. 197.

${ }^{21}$ PINA, Rui - Crónicas de Rui de Pina: D. Sancho I, D. Afonso II, D. Sancho II, D. Afonso III, D. Dinis, D. Afonso IV, D. Duarte, D. Afonso V, D. João II. Ed. Manuel Lopes de Almeida. Porto: Lello \& Irmão,1977, p. 986.

${ }^{22}$ RESENDE, Garcia de - Crónica de D. João II..., p. 196.

${ }^{23}$ RESENDE, Garcia de - Crónica de D. João II..., p. 203.
} 
as normas sociais e entregaram-se à dor em público. A rainha e a princesa foram "como mortas, levadas, e travessadas em mulas" para umas casas junto ao rio, onde permaneceram durante quinze dias em recolhimento, mudando-se ao fim desse tempo para outra casa, onde passaram a receber as visitas de condolências ${ }^{24}$. Devido ao profundo desgosto que sentiam, foram aconselhadas a não participarem no saimento.

Como forma de exteriorizar o luto, D. João e a princesa D. Isabel cortaram os seus cabelos, símbolos de alegria e sensualidade, assim como "em todo o Reino não ficou senhor, nem pessoa principal, nem homem conhecido que se não tosquiasse" ${ }^{25}$.A roupa deveria também refletir o sentimento interior de tristeza. No caso da morte de um particular, a obrigação de vestir luto ficava circunscrita aos familiares e servidores, ao passo que, na morte do rei todo o corpo político devia fazê-lo ${ }^{26}$. O rei e a rainha vestiram-se "de muito baixo pano negro", e a princesa "se vestiu de almáfega, e a cabeça coberta de negro vaso". Por sua vez, a gente comum foi vestida "de argões de burel, e almáfega, e muitos homens cingidos com baraços, e seus gibões, e pelotes, abotoados com atacas de couro, sem [a]parecer fita, nem seda" ${ }^{27}$. Os mais pobres que não tinham dinheiro para comprar burel e vestir de luto, viraram as roupas do avesso ${ }^{28}$.

Como vimos, durante o luto eram utilizados trajes de burel, estamenha ou almáfega, tecidos grosseiros e pobres que contrastavam com as luxuosas sedas ou os brocados, muitas vezes de cores vibrantes. Cada pessoa deveria possuir uma espécie de capote em burel, com um capuz de frade (designado por vaso), com que se cobriam completamente em tempos de luto. Como o burel e a almáfega não eram tingidos e tinham uma cor natural esbranquiçada ou amarelada, o branco acabou por ficar ligado à cor de luto durante a Idade Média ${ }^{29}$. O uso de tecidos grosseiros ficaria associado à penitência do corpo, e a ausência de cor nos trajes de luto ao abandono do luxo, uma vez que os

\footnotetext{
${ }^{24}$ RESENDE, Garcia de - Crónica de D. João II..., p. 196. Os monarcas portugueses e a princesa foram visitados por Enrique Enríquez, representante dos Reis Católicos, e por outros grandes senhores de Castela. Estas visitas de embaixadores faziam parte dos protocolos entre unidades políticas, e inserem-se em manifestações formais de luto, por ora não analisadas.

${ }^{25}$ RESENDE, Garcia de - Crónica de D. João II..., pp. 199-200.

${ }^{26}$ VARELA, Javier - La muerte del rey..., p. 33.

${ }^{27}$ RESENDE, Garcia de - Crónica de D. João II..., pp. 199-200.

${ }^{28}$ ARAÚJO, Ana Cristina - A Morte em Lisboa: Atitudes e Representações 1700-1830. Lisboa: Notícias Editorial, 1997, p. 239.

${ }^{29}$ MARQUES, A. H. de Oliveira - A Sociedade Medieval..., p. 216.
} 
pigmentos para tingir a roupa eram bastante caros. A roupa tornava-se, desta forma, sinónimo de dor, penitência e humildade.

O uso do preto como cor de luto foi introduzido em Portugal por altura da morte de D. João I (1433), tendo sido usado apenas por D. Duarte ${ }^{30}$. Mas só no reinado de D. Manuel I o preto se generalizou, tornando-se assim não só a cor das vestimentas como também "dos pendões fúnebres, dos panejamentos mortuários, das essas, do revestimento dos caixões, etc." ${ }^{31}$. O azul também poderia ser usado como cor de um luto mais aliviado ${ }^{32}$. Por sua vez, a duração do luto não era tão regulamentada como viria a ser nos séculos XVII e XVIII. Nesta época, o luto pelos pais teria a duração de um ano. Pela morte de D. Afonso, D. João II e D. Leonor abandonaram o luto ao fim de seis meses, o que leva a crer que o período máximo de luto seria pelos pais, diminuindo o período de tempo conforme os outros graus de parentesco ${ }^{33}$. No entanto, o luto “interior" iria ser perpétuo por parte dos monarcas e da princesa.

Logo após a morte do príncipe, D. João II teve de se debater com vários conflitos ao nível das suas próprias emoções: de um lado a dor de um pai que perdeu o seu único filho, e do outro as suas obrigações de chefe de família e senhor de um reino. Segundo António Hespanha, o papel de chefe de família, inserido no modelo doméstico e de governo da "casa", devia expandir-se para um modelo alargado de governo do povo, onde se devia ter presente as obrigações de gestão de bens e de proteção da família / comunidade $^{34}$. Desta forma, foi D. João II, que "se doía em grande maneira, e sentia sem comparação a grande dor, e magoas das Rainha, e Princesa", quem as consolou neste momento difícil. Além disso, o conselho régio e alguns religiosos recomendaram que não se entregasse tanto ao luto, por depender dele o governo do Reino. No entanto, o próprio rei acabaria por dar mostras em público da sua profunda dor: "saindo um dia pela manhã a ouvir missa fora, coberto de muito grande dó, e quando se viu sem o

\footnotetext{
${ }^{30}$ CARVALHO, Elisa Maria Domingues da Costa - "A morte régia...”, p. 208.

${ }^{31}$ MARQUES, A. H. de Oliveira - A Sociedade Medieval..., p. 217.

32 ALVES, Ana Maria - Iconologia do poder real no período manuelino: à procura de uma linguagem perdida. Lisboa: Imprensa Nacional-Casa da Moeda, 1985, pp. 74-76.

${ }^{33}$ MARQUES, A. H. de Oliveira - A Sociedade Medieval..., p. 217.

${ }^{34}$ HESPANHA, António Manuel - "Carne de uma só carne: para uma compreensão dos fundamentos histórico-antropológicos da família na época moderna”. Análise Social XXVIII:123-124 (1993), pp. 969971.
} 
Príncipe seu filho, que trazia sempre junto de si, não se pode ter que lhe não saíssem lágrimas, e como foi visto levantou-se tamanho choro, e pranto em todos..." ${ }^{35}$. Apesar dos conselhos que recebeu sobre a forma como devia lidar com a perda de D. Afonso, o facto é que D. João II ficou bastante abalado com a sua morte, entregando por um curto período de tempo certas funções governativas a homens do seu despacho ${ }^{36}$. A rainha, por sua vez, refugiou-se cada vez mais na religião, abandonando a vida mundana e aparecendo apenas nas cerimónias públicas indispensáveis ${ }^{37}$.

A princesa sofreu igualmente um enorme desgosto com a morte do marido. Apesar de o casamento ter durado apenas sete meses, os príncipes já se conheciam desde os tempos em que estiveram reféns em Moura em consequência do tratado de Alcáçovas, passando parte da sua infância juntos e desenvolvendo grande proximidade ${ }^{38}$. Desta forma, por altura da morte do príncipe, já devia existir entre eles "un fuerte lazo de afecto, nacido durante su convivencia en Moura, que explica la profunda pena y decaimiento que provoco en la infanta la muerte accidental de su marido pocos meses después del enlace, en 1491"39. A princesa abandonou o Reino em setembro desse ano, juntando-se aos seus pais em Illora, e entregou-se, num ambiente já por si devoto e fanático, a frequentes jejuns que a enfraqueciam cada vez mais, sendo também provável que se tivesse refugiado em penitências e mortificações do corpo ${ }^{40}$. Segundo Pedro Mártir de Anglería a princesa "no ha vuelto a comer en mesa después de la muerte del marido, ni ha gustado ningún manjar exquisito" ${ }^{41}$, e Rui de Pina diz-nos que comia do chão em recipientes de barro ${ }^{42}$.

\footnotetext{
${ }^{35}$ RESENDE, Garcia de - Crónica de D. João II..., pp. 198-200.

${ }^{36}$ CARVALHO, Elisa Maria Domingues da Costa - "A morte régia...", p. 177.

${ }^{37}$ SÁ, Isabel dos Guimarães - De princesa a rainha-velha..., p. 150.

38 BELENGUER, Ernest - Historia de la España moderna: desde los Reyes Católicos hasta Felipe II. Madrid: Gredos, 2011, p. 162; SÁ, Isabel dos Guimarães - Rainhas consortes..., p. 57. As terçarias de Moura constituíram o terceiro acordo da Paz de Alcáçovas, no qual se estabeleceu que Isabel e Afonso ficam reféns em Moura para assegurar o cumprimento do tratado, estipulando também o futuro matrimónio dos príncipes.

39 VAL VALDIVIESO, María Isabel del - Isabel la Católica: Una princesa “portuguesa”. Lisboa: Academia Portuguesa da História, 2005, p. 54.

${ }^{40}$ SÁ, Isabel dos Guimarães - Rainhas consortes..., p. 74.

41 Pedro Mártir de Anglería, Epistolário, epístola $\mathrm{n}^{\circ} 171$, datada de 5 de dezembro de 1496 . in RODRIGUÉZ SANCHÉZ, Ángel - "La muerte del Príncipe de Asturias, Señor de Salamanca". Revista de estudios extremeños 57:1 (2001), p. 26.

${ }^{42}$ PINA, Rui de - Crónicas de Rui de Pina..., p. 872.
} 
Ainda jovem e em idade de conceber, a princesa recusou-se a casar novamente, mesmo contra a vontade dos seus pais. As viúvas normalmente optavam por fazer um luto perpétuo que passava pelo abandono da vida mundana a favor de uma vida de devoção, chegando por vezes a envergar os hábitos religiosos de monja beneditina ou freira clarissa, não sendo, no entanto, obrigatório tomar votos religiosos ${ }^{43}$. Quando não envergavam os hábitos, os trajes utilizados eram bastante parecidos com estes últimos, usando cores como o preto, cinzento e branco para simbolizar a rejeição da alegria. Até ao Renascimento, as roupas das viúvas eram compostas, regra geral, por uma barbela, um toucado e um véu que lhes cobria a cabeça, escondendo o máximo possível o corpo e o rosto de forma a disfarçar a sua feminilidade ${ }^{44}$. Na Época Moderna esta vida de reclusão, de humildade e de penitência por parte das viúvas era vivamente aconselhada na tratadística, devendo estas levar uma vida de solidão, humildade, caridade, jejum corporal e espiritual, e a rodear-se das companhias certas ${ }^{45}$. Tudo isto teria como fim alcançar a honra de Deus, a salvação da alma e a limpeza do coração ${ }^{46}$. As obrigações políticas da princesa D. Isabel iriam, no entanto, falar mais alto do que a sua própria vontade, acabando por se casar em 1498 com o então rei de Portugal, D. Manuel I.

A morte do príncipe D. Afonso representa o expoente máximo do luto em Portugal na Idade Média, maravilhosamente descrito nas crónicas. Mais, se tivermos em conta a forma como os acontecimentos da sua morte foram relatados e lamentados pelos cronistas, em comparação com a morte de D. João II, em 1495, vemos que a importância atribuída à morte do príncipe herdeiro foi maior que a do próprio rei. É verdade que Garcia de Resende nos conta com algum pormenor a forma como foi feito luto pela morte do monarca. O cronista conta-nos que D. João II morreu "fora de Portugal, no Reino do Algarve" e que a sua tumba foi levada à Sé de Silves “com muita tristeza, e muitos grandes prantos dos senhores, e fidalgos, cavaleiros, e povos que ali eram, e acompanhavam". Todo o Reino "foi vestido de burel, almáfega e vaso, com tamanho nojo e tristeza", mandando-se apregoar pela cidade de Lisboa "que nenhum

\footnotetext{
${ }^{43}$ MARQUES, A. H. de Oliveira - A Sociedade Medieval..., p. 217.

44 TAYLOR, Lou - Mourning Dress. A Costume and Social History. London: Routledge Revivals, 2010, p. 66.

${ }^{45}$ SANTOS, Cândido Augusto Dias dos - Os Jerónimos em Portugal. Das Origens aos fins do Século XVII. Porto: Universidade do Porto, 1977. Tese de Doutoramento, pp. 257-258; SÃO JERÓNIMO Cartas espirituais de São Jerónimo. São Paulo: Edições Paulistas, 1960, p.126.

${ }^{46}$ SANTOS, Cândido Augusto Dias dos - Os Jerónimos em Portugal..., p. 261.
} 
barbeiro fizesse barba, nem cabelo, daí a seis meses, e também em outras cidades se fez isto muito bem com muito grande sentimento" 47 . No entanto, o cronista não menciona as reações da rainha D. Leonor, com quem o rei teria uma relação bastante tensa desde a morte do príncipe devido às tentativas de legitimação do seu filho bastardo D. Jorge e devido às mortes do seu irmão e do seu cunhado, ordenadas por D. João II anos antes ${ }^{48}$. Nem tão pouco utiliza o tom dramático e desesperado dos relatos da morte do príncipe, o que se poderá dever ao facto de D. João II ter assegurado a sucessão, designando em testamento o primo e cunhado D. Manuel, duque de Beja, herdeiro do reino português.

\subsection{Lutos partilhados entre Portugal e Castela: as mortes de D. Isabel de Castela, do príncipe D. Miguel da Paz e de D. Maria de Castela}

No ano de 1498, a princesa D. Isabel, que se tornara rainha de Portugal através do seu casamento com D. Manuel I em 1495, estava prestes a tornar-se rainha de Castela e Aragão, devido à morte do seu irmão D. Juan, no ano anterior. No entanto, durante a sua viagem a Saragoça para ser jurada herdeira de Aragão, e bastante fraca fisicamente, viria a falecer a 24 de agosto, horas depois de dar à luz D. Miguel da Paz.

A morte da princesa abalou todos os que lá se encontravam, sobretudo os seus pais, que viam partir o seu segundo filho, em menos de um ano ${ }^{49}$. Sabe-se que Isabel a Católica, vendo a sua filha falecer diante de si, "caiu logo sem fala como morta no chão, e o Rei dom Fernando a tomou logo nos braços, e a levou à sua câmara, e a deixou deitada como morta". A seguir, o monarca acudiu ao rei D. Manuel, que estava "muito cortado e triste", levando-o pela mão ao seu aposento e confortando-o "muito com muitas e prudentes palavras" 50 . Por último, após ter velado a filha, ter assistido aos ofícios religiosos e ter dado instrução sobre as providências a tomar, "se recolheu para seu

${ }^{47}$ RESENDE, Garcia de - Crónica de D. João II..., pp. 286-290.

${ }^{48} \mathrm{SÁ}$, Isabel dos Guimarães - De princesa a rainha-velha..., p. 149. São conhecidas, todavia, as reacções da rainha aquando a morte do seu irmão D. Diogo, duque de Viseu, ordenada por D. João II em 1484, depois de este ter premeditado o assassinato do rei. Segundo os relatos de Nicolas de Popielovo, nobre e viajante polaco que se encontrava em Portugal nesse mesmo ano, "la Reina, al saber la muerte de su hermano, se arrancaba los cabellos, torcia sus brazos, y prorrumpía en gritos y sollozos desesperados. Informado el Rey, la amenazó, si continuaba así, de envolverla en la misma causa de traición de su hermano, y entonces se quedó quieta" (VIAJES de extranjeros por España y Portugal en los siglos XV, XVI y XVII: colección de Javier Liske. Traduzido e anotado por Felix Rozanski. Madrid: Casa Editorial de Medina, 1878, p. 39).

${ }^{49}$ Em 1497, a morte do príncipe herdeiro D. Juan, aos dezassete anos de idade, teve os mesmos contornos e simbolismo da morte de D. Afonso.

${ }^{50}$ RESENDE, Garcia de - Crónica de D. João II..., p. 314. 
aposentamento sem lágrimas, com tanta segurança como se nada não fora, e como lá foi começou de chorar a filha que tanto amava, e nos braços lhe morrera, dizendo palavras de lástima". A história de um pai e senhor de um reino que primeiro acode aos outros, e só depois a si, devendo dissimular os sentimentos em público, já a vimos anteriormente. Lembro, no entanto, que a princesa D. Isabel lhe morreu nos braços, o que D. Fernando, com certeza, nunca esqueceu. Ouvindo o rei a chorar, "começou-se logo tão grande pranto em todos os paços, e tamanhos gritos, que parecia que se vinham à terra, e não havia pessoa que se não carpisse, e chorasse bravamente como se a perda fora sua" ${ }^{\text {. }}$.

A princesa D. Isabel alterou os usos do luto em Portugal. No seu testamento havia ordenado que não se usasse burel por dó, e se tomasse o preto por cor de luto ${ }^{52}$. Esta passara a ser a cor de luto oficial em Castela aquando da morte do príncipe D. Juan, seu irmão, e o mesmo aconteceu em Portugal, através de uma disposição de D. Manuel ${ }^{53}$.

O recém-nascido D. Miguel da Paz tornava-se, por morte de D. Isabel, herdeiro das coroas de Portugal, Castela e Aragão, e ficaria entregue aos cuidados dos seus avós maternos. No entanto, acabaria por viver apenas dois anos, falecendo em Granada em 1500. Não se tomou luto pelo infante mas certamente que os Reis Católicos sofreram com a sua perda, pelo abalo que representou na família, e por significar o fim das esperanças na união dos seus dois reinos. D. Manuel, por sua vez, também não manifestou luto pela morte do filho e as razões podem ser várias: ou por não o ver desde o seu nascimento, não criando laços afetivos com um filho que não conhecia; ou por não querer chamar a atenção para a falta de herdeiros; ou por ainda ter bastante tempo para voltar a casar e ter mais filhos, para assegurar a sucessão ao trono ${ }^{54}$. Seja como for, o facto de não ter tomado luto pelo príncipe não deixa de ser normal para a época. Com efeito, como afirma Bartolomé Bennassar, as pessoas estavam preparadas para a morte prematura dos recém-nascidos e das crianças muito pequenas, numa época em que a

\footnotetext{
${ }^{51}$ RESENDE, Garcia de - Crónica de D. João II..., p. 314.

${ }^{52}$ SÁ, Isabel dos Guimarães - Rainhas consortes..., p. 105; RESENDE, Garcia de - Crónica de D. João II..., p. 315.

${ }^{53}$ RODRIGUÉZ SANCHÉZ, Ángel - "La muerte del Príncipe de Asturias, Señor de Salamanca”, pp. 2324, nota 2. Isabel dos Guimarães Sá afirma, no entanto, que não encontrou "qualquer disposição emanada por D. Manuel relativa às mudanças nas formalidades do luto assinaladas por Resende...” (SÁ, Isabel dos Guimarães - Rainhas consortes..., p. 104).

${ }^{54}$ SÁ, Isabel dos Guimarães - Rainhas consortes..., p. 109.
} 
mortalidade infantil era muito elevada. Além disso, normalmente os bebés eram tirados à mãe logo quando nasciam para ser entregues a amas-de-leite, o que não permitia que se criassem laços imediatos com a mãe biológica, quando esta não morria de parto ${ }^{55}$. No entanto, quando a criança vivia alguns anos, a sua morte causava certamente desgosto aos pais e a quem a rodeava. As próprias fontes, como as crónicas, não dão informações sobre o luto por infantes pequenos, destacando apenas os casos em que perturbavam a estabilidade dinástica do reino, quando se tratava de príncipes herdeiros.

Em 1517, D. Manuel enfrentaria novamente a morte, desta feita da sua segunda mulher D. Maria de Castela, também filha dos Reis Católicos, e irmã da anterior. Ao contrário da morte de D. Isabel, na qual não se regista qualquer manifestação de luto por parte de D. Manuel, a morte de D. Maria abalaria o monarca, que no mesmo dia em que a rainha faleceu "se foi a Penha Longa onde esteve duas semanas", passando depois para o Mosteiro de Enxobregas, "donde passados oito dias se tornou para a cidade" 56 . Também Frei Luís de Sousa, no capítulo onde aborda a morte D. Maria, recorda que "parecia-lhe que devia mostrar a obrigação que tinha à defunta com morrer também ao mundo, deixar tudo e recolher-se onde só de sua alma e do serviço de Deus tratasse" ${ }^{\circledR 5}$. Não nos podemos esquecer que D. Maria foi a mãe da sua abundante prole, e que D. Manuel esteve casado com ela muitos anos. Mais uma vez se refere um período de recolhimento de duas semanas após a morte de um ente querido, deixando-nos pensar que seria uma prática comum na época.

\subsection{A morte de D. Manuel: um ponto de viragem}

D. Manuel voltaria a casar em 1518, desta feita com D. Leonor de Áustria, neta dos Reis Católicos e filha de Joana a Louca e Filipe o Belo, durando o casamento pouco tempo. Em dezembro de 1521 D. Manuel foi arrebatado por "uma febre espécie de modorra, doença de que naquele tempo em Lisboa morria muita gente", causando grande

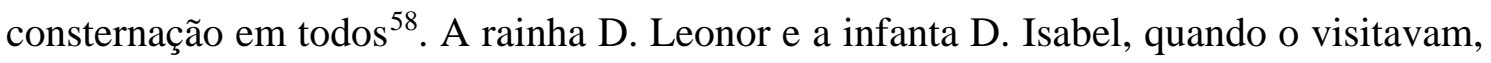

55 BENNASSAR, Bartolomé - A Cama, o Poder e a Morte: Rainhas e Princesas da Europa do Renascimento ao Iluminismo. Lisboa: Temas e Debates, 2009, p. 164.

56 GÓIS, Damião de - Chronica do Felicissimo Rei Dom Emanuel. Lisboa: Francisco Correa, 1566, IV parte, fl. $26 \mathrm{v}$.

57 SOUSA, Frei Luís de - Anais de D. João III. Ed. Manuel Rodrigues Lapa. Vol. II. Lisboa: Sá da Costa, 1938 , p. 23.

${ }^{58}$ GÓIS, Damião de - Chronica do Felicissimo..., IV parte, fl. 104 v. 
"pareciam mulheres fora de siso", sendo a rainha aconselhada a recolher-se na sua câmara, de modo a não perturbar o monarca com as "muitas lamentações e dolorosas palavras" e por não ser "convinhável vossa pessoa ser vista deles na maneira em que está" $^{59}$. Mais uma vez, a demonstração da tristeza ou desespero por parte da pessoa real era vista como inapropriada, sendo aconselhável sofrer em privado. Na sua câmara, a rainha "muito tristemente fez muito grande pranto abraçando-se muitas vezes com a infanta dona Isabel”. O Príncipe, por sua vez, "a confortava com palavras mais de siso e esforço que de vontade nem consolação que ele para si tivesse" ${ }^{\text {"60 }}$. Junto do leito do seu pai não deixou, contudo, de mostrar os seus sentimentos, tomando a bênção de $D$. Manuel "com os olhos arrasados em lágrimas" 61 , e recolhendo-se de seguida numa câmara. Ao mesmo tempo, "nestes dias sempre de muita gente estava o paço e varandas e Ribeira ocupado vigiando a morte ou vida del rei" ${ }^{62}$.

D. Manuel faleceu a 13 de dezembro de 1521, espalhando-se a nova da sua morte logo por toda a cidade. Damião de Góis lembra as "muitas lágrimas, prantos e choros que cada um fazia pela perda de um tão bom Rei e tão amigo de seus criados, e vassalos como ele sempre foi" ${ }^{63}$. Dentro do paço, chegavam "os principais senhores e regedor e governador e doutores e corregedores da cidade e corte e outras pessoas de prominência", aos quais o príncipe D. João fez um discurso "com um lenço na mão com que secava as muitas lagrimas que do intrínseco saiam". Entrecortado pela dor, consolou a todos, sendo muito notório no seu discurso "a muita prudência e aviso que nele havia em cabo da qual sobretudo lhe muito encomendou o resguardo da justiça e brevidade de seu despacho pois a eles era dado cargo de administrar o que agora muito mais cumpria e que pela indisposição del Rei seu senhor e padre não se desocupassem dos negócios do Reino e bem do povo"64.

\footnotetext{
${ }^{59}$ CORREIA, Gaspar - Crónicas de D. Manuel e de D. João III (até 1533). Ed. José Pereira da Costa. Lisboa: Academia das Ciências de Lisboa, 1992, pp. 161-162.

${ }^{60}$ CORREIA, Gaspar - Crónicas de D. Manuel, pp. 161-162.

61 SERRÃO, Joaquim Veríssimo - “A crónica de D. João III de António de Castilho". Separata de Arquivos do Centro Cultural Português. Paris: Fundação Calouste Gulbenkian, 1970, p. 370.

${ }^{62}$ CORREIA, Gaspar - Crónicas de D. Manuel..., p. 166.

${ }^{63}$ GÓIS, Damião de - Chronica do Felicissimo..., IV parte, fl. 105.

${ }^{64}$ CORREIA, Gaspar - Crónicas de D. Manuel..., p. 167.
} 
Francisco de Andrada salienta também que a dor do príncipe teria sido ainda maior que a de todos os outros, mas que nem isso o fez descuidar de dar seguimento ao enterro e às exéquias em todas as igrejas e conventos com a maior brevidade possível ${ }^{65}$. Frei Luís de Sousa lembrou também que o príncipe demonstrou "com gravíssimo sentimento o muito que amava a el-rei seu pai”, mas que "como tudo dependia já dele, tratou logo de fazer dar cumprimento ao testamento, quanto à sepultura e exéquias e ao mais que tocava ao bem de sua alma, segundo o tempo dava lugar" 66 . A julgar por estes relatos (que não podemos evidentemente seguir à letra), os cronistas dão uma imagem de grande força interior do príncipe, uma vez que teve bem presente que o seu dever de futuro rei se deveria sobrepor à sua dor. A preocupação com a continuidade da administração e dos negócios do reino e com o bem do povo, e a prontidão com que deu seguimento às cerimónias, demonstram que o príncipe, numa situação tão avassaladora como a morte do seu pai, foi tão virtuoso como um futuro monarca deveria ser.

Apesar da demonstração das emoções, não deixam de ser evidente as tentativas de dissimulação por parte da família real, especialmente do futuro rei, necessárias à manutenção da virtude da pessoa real. Esta atitude, contudo, contrastava com as manifestações de luto dos restantes fidalgos da corte, que revelavam uma continuidade das manifestações violentas de dor. O monarca foi metido num ataúde de madeira e levado por alguns fidalgos para ser enterrado em Belém. Assim que levaram o corpo do rei para baixo, "foi recebido com mui lamentáveis prantos de muitos que na sala esperavam". Descoberto o ataúde, "de todos foi visto e lhe beijaram a mão com fontes de lágrimas dos senhores e fidalgos principais". Quando colocaram a tábua por cima do ataúde, conta-nos Gaspar Correia que os "pregos não foram tão pregados com martelos como as cabeças dos que eram presentes que com elas davam muitas pancadas no ataúde e no chão que era uma mui grave cousa de ver". No caminho para o Mosteiro de Belém, as manifestações exacerbadas de dor continuaram. Entre as luzes das tochas e o negro da noite, "iam com o Rei todos os grandes senhores e prelados todos com miserável pranto e pelas ruas e janela e caminhos tudo eram gritos e prantos". Depois do enterro, fizeram-se "os prantos finais lamentados e gritados com brados e altas vozes

\footnotetext{
${ }^{65}$ ANDRADA, Francisco de - Crónica de D. João III. Ed. Manuel Lopes de Almeida. Porto: Lello \& Irmão, 1976, p. 14.

${ }^{66}$ SOUSA, Frei Luís de - Anais de D. João III..., p. 29.
}

Medievalista online $\mathrm{N}^{\circ} 22$ | Julho - Dezembro 2017 @ IEM - Instituto de Estudos Medievais 18 www2.fcsh.unl.pt/iem/medievalista 
que pareciam mais de gentes sem siso que de homens receosos da mesma morte segundo suas cabeças quebravam nas paredes e poiares e seus cabelos e barbas arrancavam e suas faces como doridas mulheres rasgavam e esbofeteavam" ${ }^{\circ}$.

Estas descrições tornam patente uma fase de transição e de ajustamento de comportamentos. À família real continuava a impor-se a dissimulação e moderação dos sentimentos de dor, ainda que surjam referências à exteriorização das emoções por parte do príncipe, da rainha e da princesa. No entanto, esta atitude contrasta com o "luto selvagem" feito pelos grandes senhores, prelados e povo, que perante a presença do corpo do rei morto e a passagem do ataúde mantiveram as práticas medievais dos prantos e da auto-inflição da dor física, como forma ritual de libertação da dor.

Logo após ter sido levantado e jurado Rei, D. João III pôde finalmente deixar a corte e isolar-se. Assim, passou dos paços da Ribeira para Santos-o-Novo, onde se aposentou nas casas de Francisco d'Eça. Quanto à rainha, a primeira determinação que tomou logo após a morte do rei foi recolher-se no Mosteiro de Odivelas, "para poder melhor sofrer o grave peso daquele trabalho e daquele nojo". Daí mudou-se com a infanta D. Isabel para as casas de Tristão da Cunha, em Enxobregas, onde frequentou os ofícios divinos, mandou socorrer os pobres que passavam fome e mandou repartir esmolas pelas freguesias aos mais necessitados. Vimos atrás que um dos comportamentos recomendados às viúvas virtuosas era, para além da reclusão, dedicar-se à prática da caridade. Depois do saímento por D. Manuel, D. João III passou-se para Santos-oVelho, fora dos muros da cidade, e a Rainha e a infanta D. Isabel para as casas do duque de Bragança, dentro dos muros da cidade ${ }^{68}$. O recolhimento continuava a melhor forma da família real fazer luto. É também de registar que D. Manuel, no seu testamento, determinou que "os criados e vassalos não deveriam trazer burel, e aos que por ele quisessem tomar luto, pedia-se que o não fizessem por mais de seis meses" ${ }^{69}$.

\footnotetext{
67 CORREIA, Gaspar - Crónicas de D. Manuel..., pp. 169-170. Sobre as atitudes dos fidalgos e da família real perante a morte de D. Manuel leia-se VICENTE, Gil - Copilaçam de todalas obras de Gil Vicente. Ed. Maria Leonor Carvalhão Buescu. Vol. II. Lisboa: Imprensa Nacional-Casa da Moeda, 1984, pp. 627-628.

68 ANDRADA, Francisco de - Crónica de D. João III..., pp. 19-44.

${ }^{69}$ BRAGA, Paulo Drumond; BRAGA, Isabel M. R. Mendes Drumond - "As duas mortes de D. Manuel: o rei e o homem”. Penélope: revista de história e ciências sociais 14 (1994), p. 13.
} 


\section{O luto durante o reinado de D. João III: mutações}

O reinado de D. João III, compreendido entre finais de 1521 e meados de 1557 , ficou marcado por dolorosos acontecimentos. O monarca assistiu nestes anos à morte de sete dos seus dez irmãos, à morte de todos os seus nove filhos legítimos, e do seu filho natural D. Duarte. Ainda assim, poucas são as referências ao luto por parte da cronística, e as que se registam revelam um luto diferente do século anterior, uma vez que "as convenções sociais já não tendiam para exprimir a violência da dor, inclinavam-se a partir de agora para a dignidade, para o controlo de si”,70.

Como vimos, os comportamentos coletivos e individuais foram-se alterando na entrada para a modernidade devido a um processo civilizacional que levou ao abandono das velhas formas tradicionais de luto e permitiu a adoção de novos comportamentos. Nobert Elias estudou este processo civilizacional, defendendo um crescente autocontrolo e uma regulação das interações humanas e das emoções devido à crescente complexidade das sociedades, no caminho para a modernidade. A rede de interdependências tornou-se cada vez mais complexa, e as ações de cada um começaram a influenciar mais o outro e, consequentemente, toda a cadeia social. Por isso, foi necessário organizar esta rede com maior rigidez, de modo a garantir uma maior estabilidade e uniformidade comportamental à sociedade, e evitar a perturbação social.

Foi na corte onde primeiro se desenvolveu essa pressão da interdependência entre os indivíduos, e a busca de um auto-controlo. Desde o século XII que o "acortesamento dos guerreiros" os colocou sob a dependência do rei, exigindo do poder central um maior controle sobre os que o rodeavam, através de uma regulação dos comportamentos por parte do príncipe, dos seus representantes e dos seus servidores. O controlo dos comportamentos era tanto mais rígido quanto mais elevada fosse a posição social do indivíduo e quantas mais ações dependessem dele. A corte situa-se, assim, durante algum tempo no topo das interdependências sociais, desencadeando comportamentos onde o cerimonial e a etiqueta desempenham papéis fundamentais. Também em Portugal, a mudança nos comportamentos, sobretudo por parte do príncipe, coincidiu com o processo de uniformização das instituições, no reinado de D. Manuel. Além

\footnotetext{
${ }^{70}$ ARIÈS, Philippe - O Homem Perante a Morte. Vol. I. Lisboa: Europa-América, 1988, p. 194.
} 
disso, a observação das pessoas dentro da corte contribuiu para o controlo e racionalização das emoções e para a contenção dos comportamentos. Os livros de maneiras permitiram estabelecer na sociedade cortesã um bom padrão de conduta, funcionando como coações exteriores tendentes a regular os comportamentos. A coação interior que o indivíduo exercia sobre si tornou-se ainda mais decisiva na sua relação com o outro. A perda de prestígio, o sentido da vergonha ou do pudor, condições essenciais à manutenção da sua condição na corte, exerciam forças coercivas sobre o cortesão, que auto-reprimia os seus impulsos numa luta constante consigo próprio ${ }^{71}$.

Por outro lado, a morte, associada ao pensamento humanista, passou a ser tida como o fim dos males e o ingresso num mundo melhor, censurando-se agora o facto de se “chorar a morte de um amigo, porque esquecia então as leis da natureza e os princípios da filosofia que nos desviam de lamentarmos as pessoas como os bens, uns e outros igualmente corruptíveis" ${ }^{72}$. Esta nova atitude do luto defendia que se aceitasse a morte de um familiar ou de alguém próximo por ser essa a vontade de Deus e por este estar melhor no outro mundo, restando apenas aceitar esta realidade sem lamentações. Isto não significa que tivesse deixado de haver medo da morte mas apenas que, como vimos, se tentasse "difundir uma atitude de auto-domínio por intermédio de uma solene ritualização do decisivo e terrível momento em que se abandona o mundo dos vivos" ${ }^{\text {73 }}$.

No entanto, "o que se fazia pela etiqueta palaciana era ainda tomado a sério pelo povo das aldeias", onde se entoavam nos acompanhamentos fúnebres "vozes descompostas" e "desordenados prantos"74. De facto, estas práticas permaneceram no seio da gente comum bem para além da Idade Média e da Reforma Católica nas regiões mais periféricas da Península Ibérica e do Mediterrâneo. O desaparecimento destes rituais e do recurso às carpideiras foi progressivo, registando-se, segundo James Amelang, duas fases distintas. Numa primeira fase, nos séculos XV e XVI, assistiu-se ao desaparecimento das carpideiras nas cidades e no seio das elites, que teriam contacto com as novas ideias da Reforma que chegavam à corte. Estas práticas permaneceram, assim, nas zonas rurais e no povo, onde os comportamentos pagãos estavam enraizados

\footnotetext{
${ }^{71}$ ELIAS, Norbert - O processo civilizacional..., pp. 202-239.

${ }^{72}$ ARIÈS, Philippe - O Homem Perante a Morte..., p. 193.

${ }^{73}$ MATTOSO, José - "O Poder e a Morte", p. 395.

${ }^{74}$ BRAGA, Teófilo - O povo português..., p. 162.
} 
e se verificava a coexistência de práticas de luto cristãs e pagãs. Estas muitas vezes eram propaladas através da convivência de cristãos com judeus, mouros e pessoas vindas de fora da Europa. Numa segunda fase, já no século XX, assistiu-se a uma "modernização do campo" e das zonas marginais, o que resultou numa mudança cultural, social e económica destas zonas, que transformaram o próprio luto ${ }^{75}$.

Em Portugal, o luto foi também objeto de um processo de privatização. As referências ao luto feito pela família real tornam-se praticamente inexistentes nas crónicas, dando lugar a descrições das cerimónias fúnebres, cada vez mais ritualizadas. Desta forma, as poucas referências ao comportamento dos monarcas perante a morte foram substituídas pelas menções a cartas trocadas entre os membros da família real ou às dos seus emissários. A separação forçada das famílias, e a impossibilidade de visitar os familiares com frequência estimulou o envio de cartas pessoais, às vezes autógrafas, entre irmãos, cunhados, pais e filhos. Os motivos eram vários, desde os nascimentos, os casamentos, as doenças, as mortes, os sucessos e insucessos militares, não existindo por vezes uma delimitação clara entre as cartas políticas e a correspondência privada ${ }^{76}$.

Assim sendo, a comunicação por carta visava diminuir distâncias entre as famílias através da partilha de novidades, opiniões ou conselhos, e exprimir, acima de tudo, sentimentos e afetos ${ }^{77}$. No entanto, essa expressão das emoções através das cartas deve ser lida com algum cuidado uma vez que, ainda que pareçam um retrato íntimo manifestado sem etiquetas e cerimónias, estão ligadas aos princípios da arte de conversação da corte, contendo muitas vezes palavras medidas e contidas, que refletiam essa mesma contenção da oralidade ${ }^{78}$. Catarina de Áustria fez grande uso da correspondência para se manter em contacto com o seu irmão Carlos V: as informações sobre a sua vida privada e quotidiana ocupam um lugar de destaque e ajudam a perceber

\footnotetext{
${ }^{75}$ AMELANG, James - "Mourning Becomes Eclectic: Ritual Lament and the Problem of Continuity". Past \& Present 187 (2005), pp. 21-30.

${ }^{76}$ BRAGA, Isabel M. R. Mendes Drumond - Um espaço, duas monarquias: (interrelações na Península Ibérica no tempo de Carlos V). Lisboa: Centro de Estudos Históricos da Universidade Nova de Lisboa, 2001, p. 87.

${ }^{77}$ LETTRES des Souverains Portugais à Charles Quint et à l'Impératrice (1528-1532): suivies en annexe de lettres de D. Maria de Velasco et du Duc de Bragance. Ed. Aude Viaud. Lisboa, Centro Cultural Calouste Gulbenkian, 1994, p. 16.

${ }^{78}$ BOUZA ÁLVAREZ, Fernando - Corre Manuscrito: una historia cultural del siglo de oro. Madrid: Marcial Pons, 2001, pp. 138-139.
} 
melhor a vida na corte portuguesa, contendo referências a factos muitas vezes ignorados pelos cronistas $^{79}$. É de salientar ainda que estas cartas são privadas pelo seu conteúdo pessoal, mas também por saírem das próprias mãos da rainha. Enfim, as informações sobre o luto, sempre mais escassas nas crónicas, passaram a ter lugar na correspondência privada, convertendo-se a carta na Época Moderna num género indispensável para reproduzir os sentimentos interiores.

\subsection{A morte dos filhos de D. João III e D. Catarina}

Os anos entre 1526 e 1539 foram fatídicos para os filhos de D. João III e D. Catarina. Foram nove (D. Afonso, D. Maria, D. Isabel, D. Beatriz, D. Manuel, D. Filipe, D. Dinis, D. João e D. António), e as suas mortes detiveram um duplo significado: aliada à dor da perda, a progressiva angústia de não conseguir assegurar a sucessão ao trono, colocando em causa a continuidade dinástica ${ }^{80}$. A dor dos monarcas foi-se tornando cada vez mais notória à medida que os viam partir, e estarem na iminência de morrer sem sucessor ao trono, tornando-se o luto pessoal sobretudo num luto político. A imagem do monarca esteve sempre associada ao vestuário negro e à ausência de ostentação ou de exibição de insígnias, revelando não só todos os desgostos que o acompanharam ao longo da vida, como também a sua simplicidade no $\operatorname{trajar}^{81}$. As crónicas referiram os problemas causados por estas mortes, embora destacando a atitude exemplar do soberano. Segundo António de Castilho, D. João III mostrou grandeza de espírito "no sofrimento a que sacrificou seu coração vendo quase cada ano um Irmão ou um filho morto (...) sem nunca lhe enxergarem fraqueza em tanta mágoa como a perda destes príncipes naturalmente lhe havia de fazer" ${ }^{\prime 2}$. Quanto à Rainha, observando a cronologia das gravidezes, abortos, nascimentos e mortes dos seus filhos, podemos imaginar os problemas de saúde a nível físico, e a dor a nível psicológico, em contraste com os seus retratos, que a mostram fisicamente forte e de carácter austero e altivo ${ }^{83}$.

\footnotetext{
${ }^{79}$ LETTRES des Souverains..., p. 25.

${ }^{80}$ BUESCU, Ana Isabel - Catarina de Áustria: (1507-1578): Infanta de Tordesilhas, Rainha de Portugal. Lisboa: A esfera dos livros, 2007, pp. 181-182; BRAGA, Isabel M. R. Mendes Drumond - Um espaço, duas monarquias..., p. 33.

${ }^{81}$ BUESCU, Ana Isabel - D. João III: 1502-1557. Lisboa: Círculo de Leitores, 2005, pp. 210-211.

${ }^{82}$ SERRÃO, Joaquim Veríssimo - "A crónica de D. João III...”, p. 362.

${ }^{83}$ LETTRES des Souverains..., pp. 60-61.
} 
As mortes dos filhos tornavam-se-lhes cada vez mais insuportáveis e sofridas, facto que transparece nas próprias crónicas, que as documentam cada vez melhor. A dor pela morte do seu primeiro filho D. Afonso, em 1526, aos três meses de idade, foi, segundo Gaspar Correia, mais visível por parte da rainha do que por parte do rei, afirmando que “o rei pela criança assim ir como anjo para o paraíso com paciência mostrou que por isso não tomava mais paixão que dar graças a Deus que the dera e o levara de que a rainha se mostrou agravada" 84 . Como vimos anteriormente a propósito do príncipe D. Miguel, as mortes das crianças, sobretudo aquelas que tinham pouca idade, não eram especialmente sentidas. Por outro lado, os monarcas tinham casado apenas há um ano, em 1525, havendo tempo para a rainha voltar a conceber outros filhos. Ainda assim, o desgosto de D. Catarina poderia dever-se ao facto de ver partir o seu primeiro filho gorando as suas expetativas de dar um herdeiro ao monarca. Em 1529, faleceu a infanta D. Isabel, da mesma idade do seu irmão. D. Maria de Velasco, camareira-mor de D. Catarina, numa carta dirigida a Carlos V, escreveu que "la ynfante llevola N. S. a el çielo y aunque hes muy chiquita les dio harta pena a Sus Altezas" ${ }^{85}$. Ou seja, a morte da infanta foi sentida pelos monarcas, abordando-se o assunto por correspondência apenas alguns meses depois, e não pela mão de D. Catarina, mas por uma das suas damas. Em 1531, faleceu aos dezassete meses a infanta D. Beatriz. A rainha revelou, meses após a morte da infanta, um desgosto e uma saudade evidente numa carta que escreveu ao seu irmão Carlos $\mathrm{V}$, na qual respondia aos pêsames e ao consolo do imperador, e onde se mostrava conformada com a vontade de Deus ${ }^{86}$. Escreveu a rainha que "N. S. la llevo para sy, y mandarme V. M. que conforme con su voluntad es bastante para lo açer pues tanta merced me açe en tener ese cuydado aunque la carta no ycyese mas su ofyçyo que no podya ser menos segun fue piedosa cosa ver su muerte y que tan paçyente y mansa era, mas todo esto curara lo que tengo dicho" ${ }^{\prime 7}$.

Estas mortes sucessivas começavam, sem dúvida, a ter grande impacto na rainha. Segundo Aude Viaud, se D. Catarina normalmente expressava abertamente os seus

\footnotetext{
${ }^{84}$ CORREIA, Gaspar - Crónicas de D. Manuel..., p. 228.

${ }^{85}$ Carta de D. Maria Velasco, datada de 28 de setembro de 1529. in LETTRES des Souverais..., doc. 16, p. 232; BUESCU, Ana Isabel - Catarina de Áustria..., p. 194.

${ }^{86}$ BUESCU, Ana Isabel - Catarina de Áustria..., p.196.

${ }^{87}$ Carta de D. Catarina a Carlos V, datada de 11 de dezembro de 1531. in LETTRES des Souverains..., doc. 83 , p. 173.
} 
afetos pelo Imperador seu irmão, em relação às próprias desgraças demonstrava, até então, um domínio dos seus sentimentos. No entanto, na morte da infanta D. Beatriz, confidenciou ao irmão toda a sua dor em termos comoventes. Além disso, a escrita irregular desta carta e as suas muitas rasuras e manchas de tinta refletem o estado de cansaço físico e mental D. Catarina, mais de quatro meses após o falecimento da filha ${ }^{88}$.

Durante seis anos não se registaram novas mortes, tendo a rainha dado à luz mais três filhos: D. Manuel, D. Filipe e D. Dinis. Mas em 1537 o príncipe D. Dinis faleceu sem completar os dois anos de idade, e poucos meses depois foi a vez de D. Manuel, com menos de seis. Em 1539, faleceu o príncipe Filipe, também perto da mesma idade. Segundo Francisco de Andrada, a sua morte causou "assaz grande dor e sentimento não somente de suas Altezas, mas de todo o reino em geral pelas boas esperanças que de si dava naquela tenra idade". No dia seguinte ao enterro no Mosteiro de Belém, conta-nos o cronista que o rei ouviu missa, comeu retirado com pouca gente à sua volta, e não consentiu que se fizesse dó, nem mudança de roupas. Sabemos ainda que se recolheu no Mosteiro de Penha Longa, ao lado da vila de Sintra, e a rainha no Mosteiro de Madre Deus, onde permaneceram alguns dias ${ }^{89}$. Esta morte "significara para os reis uma dor particular, pelos laços de amor e de afecto que cresciam com o passar dos anos, pelas expectativas que pai e mãe neles iam depositando" 90 . No entanto, as descrições das atitudes dos monarcas perante a morte dos filhos não são tão extensas como as anteriores, o que revela a tendência para a contenção e a privatização dos sentimentos. No início de 1540, faleceu o último filho que a rainha deu à luz, D. António, antes de completar o ano de idade. Ana Isabel Buescu, tendo em conta os testemunhos do embaixador de Castela, Luís Sarmiento, afirma que os monarcas evidenciaram um grande desgosto, não por sofrerem mais com esta morte, mas por ser cada vez mais difícil dissimular a dor e a consternação que os assolava.

Entrado o ano de 1540, apenas restavam aos monarcas dois filhos, D. Maria e D. João, tornando-se este último herdeiro ao trono. No entanto, em 1545, a princesa D. Maria acabaria por falecer ao dar à luz o infante D. Carlos. D. Filipe de Espanha (futuro Filipe

\footnotetext{
${ }^{88}$ LETTRES des Souverains..., pp. 67-68.

${ }^{89}$ ANDRADA, Francisco de - Crónica de D. João III..., p. 799.

${ }^{90}$ BUESCU, Ana Isabel - Catarina de Áustria..., pp. 206-209.
} 
II), seu marido, retirou-se três semanas para o mosteiro de Abrojo, perto de Valladolid $^{91}$. Não encontrei nenhuma informação sobre o luto dos pais, mas a morte da princesa constituiu certamente mais um duro golpe na vida dos monarcas.

A partir do ano de 1545, todos depositaram todas as esperanças no único herdeiro sobrevivente, D. João, de saúde muito frágil. Mas em janeiro de 1554, casado com D. Joana de Áustria, e encontrando-se esta grávida, o príncipe adoeceu gravemente de diabetes juvenis, acabando por falecer aos dezasseis anos de idade. Mais uma vez a história repetia-se. A morte do príncipe, ainda jovem, de certa forma inesperada, abalou profundamente os monarcas e os portugueses em geral. Esta morte colocou "todos os vassalos e naturais por uma parte em contínuas lágrimas e tristeza por aquela tamanha perda" e pela angústia que trazia ao reino, pois partira aquele que até à data lhes tinha dado a esperança da independência. Neste sentido, todos passaram a depositar as esperanças na criança que estaria para nascer.

A morte do príncipe foi ocultada à princesa para não perturbar o final da gravidez. Esta apenas podia receber visitas do rei, da rainha e das suas damas, e estes não podiam mostrar dor na sua presença. Só após o nascimento e batismo do príncipe D. Sebastião, a princesa teve a notícia oficial da morte de D. João, dando-se início ao luto oficial e público, com exéquias solenes no Mosteiro de Belém ${ }^{92}$. Até este tempo não se tinha mudado a armação e o ornamento das casas, armando-se só depois a "sua câmara de pano branco com um lençol por cima da cama, e na cabeça olhandilha tinta"93.

Por sua vez, D. Joana "vistióse de sarga, púsose tocas negras y pretendió cortarse el rubio cabello, título regalado de su hermosura, pero el Rey no se lo consintió, permitiéndole únicamente recluirse en sus habitaciones, donde todo era silencio, soledad y recogimiento" 94 . O corte dos cabelos foi censurado, ao contrário do que seria noutros tempos, embora o recolhimento se continuasse a praticar como forma de luto. BañosGarcía refere ainda que a princesa "renunciou a todas as vestes e ostentações inúteis e

\footnotetext{
${ }^{91}$ BRAGA, Isabel M. R. Mendes Drumond - Um espaço, duas monarquias..., p. 70.

92 VELOSO, J. M. de Queirós - D. Sebastião: 1554-1578. Lisboa: Empresa Nacional de Publicidade, 1935, p. 18.

${ }^{93}$ ANDRADA, Francisco de - Crónica de D. João III..., p. 1192.

${ }^{94}$ DANVILA, Alfonso - Felipe II y el Don Sebastián de Portugal. Madrid: Espasa Calpe, 1954, p. 57.
} 
distribuiu-as entre os necessitados, decidida a manter o luto, para o resto da vida, para não apagar as recordações da sua curta convivência ao lado do esposo" "95. Nos retratos posteriores a este período, a princesa surge vestida de luto, revelando um vestuário de dó mais elegante do que os tempos anteriores, mantendo o uso do preto e do branco, bem como dos toucados para esconder o cabelo. A moda do Renascimento é visível sobretudo no estilo destes últimos, na escolha do tecido dos véus (seda transparente, por exemplo) ou nos penteados elegantes usados por baixo destes ${ }^{96}$.

Por motivos políticos, D. Joana teve de abandonar a corte portuguesa coberta de luto. A princesa desejou viajar com discrição e sem ser vista, permanecendo afastada da corte até à sua partida, sozinha com a sua dor, passando "muitas horas no oratório privado, gemendo e lamentando a sua sorte, recusando o contacto com outras pessoas" ${ }^{\text {"97. Em }}$ Castela, adotou "uma vida de recolhimento, quase de reclusão monástica, interrompida apenas pelas obrigações públicas que desempenha"98. A princesa nunca mais tirou o luto.

\subsection{A morte do rei D. João III}

Três anos mais tarde, em 1557, a morte voltaria à corte, levando agora D. João III. A crónica de Francisco de Andrada é quase muda no que diz respeito ao luto feito pela morte do rei. No entanto, através de outras fontes, como um relato de Frei Tomé de Jesus, datado de 14 de junho de 1557, conseguimos conhecer os momentos seguintes à sua morte rei com bastante pormenor. Sabemos que a rainha, que esteve do seu lado até ao seu último suspiro, lhe fechou os olhos, se cobriu de luto e se dirigiu ao oratório onde se encontrava a relíquia de S. Sebastião e onde, na companhia do padre Montoya e "sem nenhum extremo, mostrou estar muito conforme com a vontade do Senhor Deus".

\footnotetext{
95 BAÑOS-GARCÍA, Antonio Villacorta - D. Sebastião: rei de Portugal. Lisboa: A esfera dos livros, 2006, p. 21.

96 TAYLOR, Lou - Mourning Dress..., pp. 72-76.

97 BAÑOS-GARCÍA, Antonio Villacorta - D. Sebastião..., p. 22.

98 CRUZ, Maria Augusta Lima - D. Sebastião. Lisboa: Círculo de Leitores, 2006, pp. 27-28. D. Joana torna-se regente de Castela na ausência do seu irmão D. Filipe. D. Joana, como também D. Catarina, regente de Portugal à morte de D. João III, vão representar uma nova imagem de viúva. De facto, a sua imagem deixa de estar ligada apenas à reclusão e à religiosidade, para se associar à plena capacidade de decisão política e a uma crescente valorização do papel de mulher nas elites da sociedade moderna. As viúvas adquiriram, na Europa do Renascimento, "um papel importante na governação dos Estados, na administração e gestão das questões políticas, incluindo negociações internacionais" (BENNASSAR, Bartolomé - A cama, o poder e a morte..., pp. 178-179).
} 
Frei Tomé de Jesus, que se dirigiu para o paço logo após a morte do rei, dá a conhecer o contraste entre o luto feito nas ruas e o luto no palácio real. Segundo o frade, "achámos pelas ruas e Ribeira tudo cheio de pranto, e de gritos, e de muita gente", tendo sido difícil aceder ao paço. Uma vez no paço, "ninguém se ouvia com gritos, e soluços, uns em pé, outros por esse chão: uns choravam, outros gemiam, outros amarelos estavam pasmados com ver morte tão súbita e com desamparo tão de repente, e de improviso, estavam todos atónitos, e sentidos”. Após se ter rezado, lido o testamento, cuidado e velado o corpo, tudo com muita solenidade e contenção, o féretro foi levado do paço. Nas ruas, novamente se assistiu ao grande pranto da multidão: "Eu nunca vi tanta gente, nem tanto grito e choro, nem faces ensanguentadas e arranhadas, nem barbas depenadas, como então vi" ${ }^{99}$. As formas de luto pautadas pela violência física mantinham-se no seio da gente comum, e com os mesmos contornos da época anterior.

Passava assim a existir um grande contraste entre as expressões de dor da gente comum, e as da família real, que tinha de agir conforme a sua condição, revelando uma atitude fria e apática. A rainha não compareceu ao acompanhamento, ficando no paço juntamente com o cardeal D. Henrique ${ }^{100}$, nem tão pouco assistiu à primeira reunião do conselho régio que foi realizada para tratar do assunto da regência, por motivo de nojo ${ }^{101}$. O cardeal D. Henrique, por sua vez, não derramou nenhuma lágrima pela morte do rei e vestiu de roxo, em sinal de luto ${ }^{102}$. A nova atitude de moderação e racionalização das emoções da família real é bastante vincada, assim como começa a ficar bem presente a crença cada vez maior na vida eterna e na piedade de Deus.

\section{Conclusões}

Ao analisar o período compreendido entre D. João II e D. João III, podemos afirmar que se assistiu na corte ao abandono das velhas formas medievais dos prantos e das lamentações, verificando-se uma "modernização" dos comportamentos, marcada por

\footnotetext{
99 "Relato de Frei Tomé de Jesus". in CASTELO BRANCO, Camilo - Noites de Insónia. 4ª ed., vol. 1. Lisboa: Bonecos Rebeldes, 2008, p. 32.

${ }^{100}$ ANDRADA, Francisco de - Crónica de D. João III..., p. 1249.

${ }^{101}$ CRUZ, Maria Augusta Lima - D. Sebastião..., p.38.

102 BUESCU, Ana Isabel - D. João III..., p. 285; CASTELO BRANCO, Camilo - Noites de Insónia..., p. 34. O roxo expressava realeza e era a cor de luto dos cardeais e dos reis de França (DAVEY, Richard $-A$ History of Mourning. London: Create Space Independent Publishing Platform, 2013, p. 90).
} 
uma postura fria na aparência, de racionalidade e contenção, claramente devedora do "processo civilizacional” que se começou a afirmar no início do século XVI.

Comparando os finais do século XV com os meados do século XVI, verificamos que as demonstrações de luto pela morte do príncipe D. Afonso foram muito mais marcadas pela expressão das emoções, quer por parte da família real, quer por parte do povo, ambas largamente descritas nas crónicas. Durante o reinado de D. João III, o luto tornou-se tão discreto e racionalizado que até as crónicas acabaram por o silenciar ou mencionar superficialmente. São escassos os relatos sobre o luto feito pela morte dos pequenos infantes, da princesa D. Maria e do príncipe D. João. Mesmo na morte do monarca, as informações sobre o luto da rainha são quase inexistentes. Apenas no luto da princesa D. Joana pela morte do príncipe D. João verificamos uma pequena continuidade da tradição medieval, no que diz respeito à sua vontade em cortar os cabelos, intenção que D. João III impediu. Aquando da morte do príncipe D. João e de D. João III, a tradição dos prantos permaneceu no seio da gente comum, onde os comportamentos pagãos estavam bastante enraizados, e onde se verificava a coexistência de práticas de luto cristãs e pagãs, mantendo-se até um passado recente.

O luto público dos monarcas passou cada vez mais a exprimir-se não através de gestos exacerbados, mas através das cerimónias fúnebres, durante as quais se ritualizavam todas as ações e comportamentos. A própria literatura desenvolveu géneros que desembocaram em fórmulas normalizadas de expressar o luto, não faltando nas exéquias as pregações fúnebres, os panegíricos e as elegias, recitados para comover o público e elogiar o defunto de forma teatral e por vezes dramática. Com o tempo, a própria família real deixou de estar presente nas cerimónias fúnebres. No século XIX, os parentes mais próximos já não acompanhavam os funerais dos seus, seguindo o ataúde apenas até à porta do palácio ${ }^{103}$, revelando uma tentativa de dissimulação da dor e das emoções, tornando-as privadas e "domésticas".

Por fim, podemos ainda concluir a simbiose estreita entre luto e política. De facto, as manifestações de luto tinham uma relação direta com a importância política do defunto,

${ }^{103}$ LOPES, Maria Antónia - Rainhas que o povo amou: Estefânia de Hohenzollern, Maria Pia de Saboia. Lisboa: Círculo de Leitores, 2011, p. 88.

Medievalista online $\mathrm{N}^{\circ} 22$ | Julho - Dezembro 2017 @ IEM - Instituto de Estudos Medievais 29 www2.fcsh.unl.pt/iem/medievalista 
mais visíveis na morte dos monarcas e ou de príncipes herdeiros, momentos de crise política que afetavam não só a coroa como também as comunidades. Estas mortes eram especialmente dramáticas uma vez que colocavam em causa a continuidade do trono e consequentemente a independência do Reino. Desta forma, não só a pessoa real se via confrontada com a dor de perder um filho ou um cônjuge, como a comunidade política se sentia órfã perante o vazio político que essa morte provocava.

Em suma, assistimos a um "processo civilizacional" e a um "processo de privatização" do luto, que modificou para sempre os seus contornos. As manifestações de luto, associadas também à importância política do defunto, passaram cada vez mais para a esfera íntima e privada, deixando de se exprimir em público. Os sentimentos de dor e saudade passam a ser expressos sobretudo através das cartas familiares e privadas trocadas entre os membros da família real ou pessoas próximas destes, ficando por vezes guardados apenas nos corações dos enlutados, aos quais nunca teremos acesso.

\section{Referências bibliográficas:}

\section{Fontes impressas}

ANDRADA, Francisco de - Crónica de D. João III. Ed. Manuel Lopes de Almeida. Porto: Lello \& Irmão, 1976.

CORREIA, Gaspar - Crónicas de D. Manuel e de D. João III (até 1533). Ed. José Pereira da Costa. Lisboa: Academia das Ciências de Lisboa, 1992.

GÓIS, Damião de - Chronica do Felicissimo Rei Dom Emanuel. Lisboa: Francisco Correa, 1566.

LETTRES des Souverains Portugais à Charles Quint et à l'Impératrice (1528-1532): suivies en annexe de lettres de D. Maria de Velasco et du Duc de Bragance. Ed. Aude Viaud. Lisboa: Centro Cultural Calouste Gulbenkian, 1994. 
PINA, Rui de - Crónicas de Rui de Pina: D. Sancho I, D. Afonso II, D. Sancho II, D. Afonso III, D. Dinis, D. Afonso IV, D. Duarte, D. Afonso V, D. João II. Ed. Manuel Lopes de Almeida. Porto: Lello \& Irmão, 1977.

RESENDE, Garcia de - Crónica de D. João II e Miscelânea. Ed. Joaquim Veríssimo Serrão. Lisboa: Imprensa Nacional-Casa da Moeda, 1991.

SÃO JERÓNIMO - Cartas espirituais de São Jerónimo. São Paulo: Edições Paulistas, 1960 .

SERRÃO, Joaquim Veríssimo - “A crónica de D. João III de António de Castilho”. Separata de Arquivos do Centro Cultural Português. Paris: Fundação Calouste Gulbenkian, 1970.

SOUSA, Frei Luís de - Anais de D. João III. Ed. Manuel Rodrigues Lapa. Vol. I-II. Lisboa: Sá da Costa, 1938.

VIAJES de extranjeros por España y Portugal en los siglos XV, XVI y XVII: colección de Javier Liske. Traduzido e anotado por Felix Rozanski. Madrid: Casa Editorial de Medina, 1878.

VICENTE, Gil - Copilaçam de todalas obras de Gil Vicente. Ed. Maria Leonor Carvalhão Buescu. Vol. II. Lisboa: Imprensa Nacional-Casa da Moeda, 1984.

\section{Estudos}

ALVES, Ana Maria - Iconologia do poder real no período manuelino: à procura de uma linguagem perdida. Lisboa: Imprensa Nacional-Casa da Moeda, 1985.

AMELANG, James - "Mourning Becomes Eclectic: Ritual Lament and the Problem of Continuity”. Past \& Present 187 (2005), pp. 3-31.

ARAÚJO, Ana Cristina - A Morte em Lisboa: Atitudes e Representações 1700-1830. Lisboa: Notícias Editorial, 1997. 
ARIÈS, Philippe - O Homem Perante a Morte. Vol. I. Lisboa: Europa-América, 1998.

BAÑOS-GARCÍA, Antonio Villacorta - D. Sebastião: rei de Portugal. Lisboa: A esfera dos livros, 2006.

BEIRANTE, Maria Ângela - "Para a história da morte em Portugal (séc. XII-XIV)". in Estudos de História de Portugal. Homenagem a A. H. Oliveira Marques. Vol. I: Séc. VXVI. Lisboa: Estampa, 1982, pp. 357-383.

BELENGUER, Ernest - Historia de la España moderna: desde los Reyes Católicos hasta Felipe II. Madrid: Gredos, 2011.

BENNASSAR, Bartolomé - A Cama, o Poder e a Morte: Rainhas e Princesas da Europa do Renascimento ao Iluminismo. Lisboa: Temas e Debates, 2009.

BOUZA ÁLVAREZ, Fernando - Corre Manuscrito: una historia cultural del siglo de oro. Madrid: Marcial Pons, 2001.

BRAGA, Isabel M. R. Mendes Drumond - Um espaço, duas monarquias: (interrelações na Península Ibérica no tempo de Carlos V). Lisboa: Centro de Estudos Históricos da Universidade Nova de Lisboa, 2001.

BRAGA, Paulo Drumond; BRAGA, Isabel M. R. Mendes Drumond - “As duas mortes de D. Manuel: o rei e o homem". Penélope: revista de história e ciências sociais 14 (1994), pp. 11-22.

BRAGA, Teófilo - O povo português nos seus costumes, crenças e tradições. Vol. I. Lisboa: Publicações Dom Quixote, 1985.

BUESCU, Ana Isabel - Catarina de Áustria: (1507-1578): Infanta de Tordesilhas, Rainha de Portugal. Lisboa: A esfera dos livros, 2007.

- D. João III: 1502-1557. Lisboa: Círculo de Leitores, 2005. 
CARVALHO, Elisa Maria Domingues da Costa - "A Morte Régia em Portugal na Idade Média: Aspectos Rituais e Atitudes Perante a Morte". Cadernos do Noroeste 9:2 (1996), pp. 157-248.

CASTELO BRANCO, Camilo - Noites de Insónia. 4ª ed., vol. 1. Lisboa: Bonecos Rebeldes, 2008.

CRUZ, Maria Augusta Lima - D. Sebastião. Lisboa: Círculo de Leitores, 2006.

DANVILA, Alfonso - Felipe II y el Don Sebastián de Portugal. Madrid: Espasa Calpe, 1954.

DAVEY, Richard - A History of Mourning. London: Create Space Independent Publishing Platform, 2013.

DUBY, Georges - El amor en la Edad Media y otros ensayos. Madrid: Alianza Editorial, 1990.

ELIAS, Nobert - O processo civilizacional: investigações sociogenéticas $e$ psicogenéticas. Vol. 2. Lisboa: Publicações Dom Quixote, 1990.

FREVERT, Ute - Emotions in History: Lost and Found. Budapest: Central European University Press, 2011.

HESPANHA, António Manuel - “Carne de uma só carne: para uma compreensão dos fundamentos histórico-antropológicos da família na época moderna”. Análise Social XXVIII:123-124 (1993), pp. 951-973.

IKEGAMI, Eiko - "Emotions". in RUBLACK, Ulinka (ed.) - A concise companion to history. Oxford: Oxford University Press, 2012, pp. 333-440.

LOPES, Maria Antónia - Rainhas que o povo amou: Estefânia de Hohenzollern, Maria Pia de Saboia. Lisboa: Círculo de Leitores, 2011. 
MARQUES, A. H. de Oliveira - A Sociedade Medieval Portuguesa. $3^{\mathrm{a}}$ ed. Lisboa: Livraria Sá da Costa, 1974.

MATTOSO, José - “O Poder e a Morte”. Anuário de Estudos Medievais 25 (1995), pp. $395-427$.

- O Reino dos Mortos na Idade Média Peninsular. Lisboa: João Sá da Costa, 1996.

- "Pressupostos Mentais do Culto dos Mortos". Arqueologia: Revista do Campo Arqueológico de Mértola 5 (1997), pp. 5-11.

RODRIGUÉZ SANCHÉZ, Ángel - "La muerte del Príncipe de Asturias, Señor de Salamanca”. Revista de estudios extremeños 57:1(2001), pp. 23-48.

SÁ, Isabel dos Guimarães - De princesa a rainha-velha: Leonor de Lencastre. Lisboa: Círculo de Leitores, 2011.

- Rainhas consortes de D. Manuel I: Isabel de Castela, Maria de Castela e Leonor da Áustria. Lisboa: Círculo de Leitores, 2012.

SANTOS, Cândido Augusto Dias dos - Os Jerónimos em Portugal. Das Origens aos fins do Século XVII. Porto: Universidade do Porto, 1977. Tese de Doutoramento.

TAUSIET, María; AMELANG, James (ed.) - Accidentes del Alma: Las Emociones en la Edad Moderna. Madrid: Abada Editores, 2009.

TAYLOR, Lou - Mourning Dress. A Costume and Social History. London: Routledge Revivals, 2010.

VAL VALDIVIESO, María Isabel del - Isabel la Católica: Una princesa “portuguesa”. Lisboa: Academia Portuguesa da História, 2005. 
VARELA, Javier - La muerte del rey: el ceremonial funerario de la monarquía española (1500-1885). Madrid: Turner, 1990.

VASCONCELOS, J. Leite de - Etnografia portuguesa. Vol. X. Lisboa: Imprensa Nacional-Casa da Moeda, 2007.

VELOSO, J. M. de Queirós - D. Sebastião: 1554-1578. Lisboa: Empresa Nacional de Publicidade, 1935.

\section{COMO CITAR ESTE ARTIGO}

\section{Referência electrónica:}

Lopes, Ana Mafalda - "O Luto em Portugal: da Corte à Gente Comum (séculos XVXVI)”. Medievalista 22 (Julho-Dezembro 2017). [Em linha] [Consultado dd.mm.aaaa]. Disponível em http://www2.fcsh.unl.pt/iem/medievalista/MEDIEVALISTA22/lopes2207.html ISSN 1646-740X.

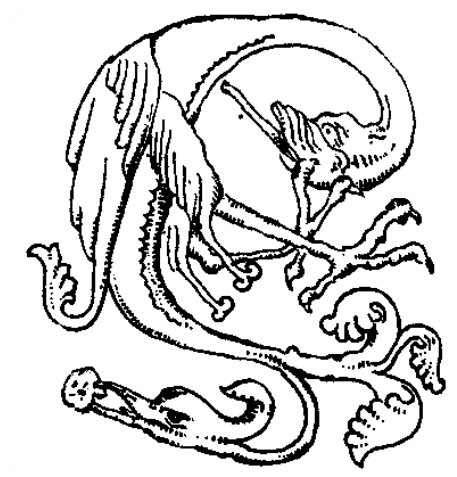

